\title{
Astrobiology
}

Astrobiology Manuscript Central: http://mc.manuscriptcentral.com/astrobiology

\section{Evaluation of the Tindouf Basin Region in Southern Morocco as an Analog Site for Soil Geochemistry on Noachian Mars}

\begin{tabular}{|r|l|}
\hline Journal: & Astrobiology \\
\hline Manuscript ID & AST-2016-1557.R3 \\
\hline Manuscript Type: & Research Articles (Papers) \\
\hline Date Submitted by the Author: & 29-Mar-2017 \\
\hline Complete List of Authors: & $\begin{array}{l}\text { Oberlin, Elizabeth; Tufts University, Dept. of Chemistry } \\
\text { Claire, Mark; University of St. Andrews, Dept. of Earth and Environmental } \\
\text { Sciences } \\
\text { Kounaves, Samuel; Tufts University, Dept. of Chemistry }\end{array}$ \\
\hline Keyword: & Mars, Analog, Atacama Desert, Mars Meteorites, Planetary Environments \\
\hline Manuscript Keywords (Search & Mars analogs, Antarctica, Morocco, oxyanions, nitrate \\
\hline \multicolumn{2}{|l}{} \\
\hline
\end{tabular}

\section{SCHOLARONE ${ }^{\text {m }}$}

Manuscripts 
${ }^{1}$ Department of Chemistry, Tufts University, Medford, Massachusetts

Address correspondence to:

\author{
Elizabeth A. Oberlin, ${ }^{1}$ Mark W. Claire, ${ }^{2,3,4}$ and Samuel P. Kounaves ${ }^{1,5}$
}

${ }^{2}$ School of Earth \& Environmental Sciences, University of St Andrews, UK

${ }^{3}$ Centre for Exoplanet Science, University of St Andrews, UK

${ }^{4}$ Blue Marble Space Institute of Science, 1001 4th Ave, Seattle, WA USA

${ }^{5}$ Department of Earth Science \& Engineering, Imperial College London, UK

\title{
Samuel Kounaves
}

Department of Chemistry

Tufts University

Medford, MA 02155

29 E-mail: samuel.kounaves@tufts.edu

30

31

32

33 34 
36 Locations on Earth which provide insights into processes that may be occurring or

37 may have occurred throughout martian history are often broadly deemed "Mars

38 analog environments." As no single locale can precisely represent a past or

39 present martian environment, it is important to focus on characterization of

40 terrestrial processes which produce analogous features to those observed in

41 specific regions of Mars, or if possible specific time periods during Martian

42 history. Here, we report on the preservation of ionic species in soil samples

43 collected from the Tindouf region of Morocco and compare them with the

44 McMurdo Dry Valleys of Antarctica, the Atacama Desert in Chile, the Mars

45 meteorite EETA79001, and the in-situ Mars analyses from the Phoenix Wet

46 Chemistry Laboratory (WCL). The Morocco samples show the greatest similarity

47 with those from Victoria Valley (VV), Beacon Valley (BV) and the Atacama,

48 while being consistently depleted compared to University Valley (UV) and

49 enriched compared to Taylor Valley (TV). The $\mathrm{NO}_{3} / \mathrm{Cl}$ ratios are most similar to

$50 \mathrm{VV}$ and Atacama while the $\mathrm{SO}_{4} / \mathrm{Cl}$ ratios are similar to those from $\mathrm{BV}, \mathrm{VV}$, and

51 the Atacama. While perchlorate in the Morocco samples are typically lower than

52 other analog sites, conditions in the region are sufficiently arid to retain

53 oxychlorines at detectable levels. Our results suggest that the Tindouf Basin in

54 Morocco can serve as a suitable analog for the soil geochemistry and subsequent

55 aridificiation of the Noachian epoch on Mars.

Kew words or phrases:

58 Mars analogs, Antarctica, Morocco, oxyanions, perchlorate, nitrate 59 
Submitted to Astrobiology (Special Issue)

1. Introduction

6

The obliquity of Mars has fluctuated throughout the historical martian epochs

62 (Ward, 1973; Touma and Wisdom, 1993; Laskar et al., 2004) causing variations

63 in climate that likely resulted in warmer conditions than are presently observed.

64 Phyllosilicate and evaporite minerals at discrete but globally distributed

65 locations on the surface (Langevin et al., 2005; Mangold et al., 2012; Bibring et

66 al., 2006; Ehlmann et al., 2013; McLennan et al., 2005; Wray et al., 2009;

67 Arvidson et al., 2014; Toon et al., 1980) support the hypothesis that liquid water

68 influenced the martian surface in the past and that the current state of Mars

69 results from the prolonged aridification of the martian environment as aqueous

70 availability decreased with time. The pedogenic processes that occurred during

71 these episodes distributed soluble ionic species that remain as geochemical

72 proxies that can be used to interpret historical climate patterns.

73 The relative ratios and distribution patterns of salts and their highly soluble

74 anions are commonly examined in order to understand the effects of different

75 degrees of aridity on the geochemical record (Claridge and Campbell, 1977;

76 Cary et al., 1979; Bao et al., 2004; Ewing et al., 2006; Keys and Williams,

77 1981; Zhu and Yang, 2010; Tamppari et al., 2012; Toner et al., 2013; Jackson et

$78 a l ., 2015)$. The distribution profiles of accumulated salts in arid soils is a

79 function of their production rates and the duration of aridity. The primary sink

80 for these salts in temperate climates is rainwater flushing of soils to rivers and 
81 groundwater, while in polar regions, mobilization by snowmelt or deliquescence

82 dominates. Thus, comparing environments with similar production mechanisms

83 (generally atmospheric) but differing degrees of aridity can provide insight into

84 the geochemical mechanisms that may have acted during the prolonged

85 aridification of the martian surface. Here, we compare and contrast the ratios of

86 soluble ions in previously suggested "Mars analog" environments with the

87 Tindouf Basin, Morocco, specifically the region of the strewn field of the Mars

88 meteorite, Tissint (Aoudjehane et al., 2012). In particular, we argue that there is

89 no such thing as a unique terrestrial Mars analog locale - rather that Earth

90 contains multiple locations which may serve as analogs for various specific

91 processes at distinct time periods in martian history.

92

93 1.1. Introduction to Terrestrial Environments proposed as "Mars Analogs"

94 1.1.1. McMurdo Dry Valleys, Antarctica. Due to their prolonged state as

95 cold hyperarid deserts, the McMurdo Dry Valleys (MDV) are the most similar of

96 any terrestrial site to the environmental and geological conditions on Mars (both

97 past and present) and thus have been widely used as geochemical and geological

98 martian analogs (Mahaney, 2001; Dickinson and Rosen, 2003; Tamppari et al.,

99 2012; Stroble et al., 2013). While the dry valleys are named as such due to their

100 complete lack of rainfall, except for a few reported instances in coastal MDV they

101 experience precipitation in the form of snowfall, often blown in by the winds. 
102 Most of this snow sublimates in the summer, but there is transfer between

103 snow/soil/permafrost profiles which influences anion profiles (Toner et al., 2013).

104 The different valleys within the MDV can be classified within three distinct

105 climate regions depending on elevation and distance from the coast, which vary in

106 temperature and aqueous availability (Marchant and Head, 2007). Individual

107 valleys can thus be compared in order to understand the effects of the changing

108 martian climate on soil geochemistry. In this way, the relative concentrations of

109 soluble salts between the lower-elevation Taylor Valley (TV), mid-elevation

110 Beacon Valley (BV), through the highest-elevation University Valley (UV)

111 (Tamppari et al., 2012; Stroble et al., 2013; Jackson et al., 2016), can potentially

112 provide insight into the shift in salt accumulation from the martian Noachian to

113 the early Amazonian epochs. These localized environments, which can serve as

114 geochemical analogs throughout the most abrupt climate change periods on Mars,

115 is a uniquely valuable feature of the MDV. However, their remote location and

116 extreme environment hinders accessibility.

117 1.1.2. Atacama Desert, Chile. The Atacama Desert is the most arid

118 nonpolar desert on Earth. Sedimentological data suggests that it has existed as a

119 stable arid region for the past $150 \mathrm{Ma}$ (Hartley et al., 2005), with evidence of

120 cyclic variations between arid and hyperarid over the past $14 \mathrm{Ma}$ (Jordan et al.,

121 2014). Although the average temperatures in the Atacama of about $16^{\circ} \mathrm{C}$ (McKay

122 et al., 2003) are much warmer than modern Mars, the hyperarid core of the 
123 Atacama features Earth's lowest total precipitation, measured at $<1 \mathrm{~mm} / \mathrm{yr}$ in the

124 Yungay region (Navarro-González et al., 2003), with even more hyperarid

125 subregions recently identified (Azua-Bustos et al., 2015). The soils found in the

126 Atacama are characterized by high levels of oxyanions such as sulfate $\left(\mathrm{SO}_{4}{ }^{=}\right)$,

127 nitrate $\left(\mathrm{NO}_{3}{ }^{-}\right)$, and perchlorate $\left(\mathrm{ClO}_{4}{ }^{-}\right)$, as the result of atmospheric or volcanic

128 deposition and input from coastal fog in some regions (Jackson et al., 2005; Bao

129 et al., 2004; Michalski et al., 2004). The relative accessibility of the Atacama has

130 yielded key insights into the geochemistry of hyperarid soils and the processes

131 that drive them (Bao et al., 2004; Ewing et al., 2006; Hartley et al., 2005).

132 1.1.3. Other warm deserts. In order to interpret data from hyperarid soils

133 on Earth in terms of historical martian climates, it is necessary to extend these

134 insights across degrees of aridity. Hyperarid soils on Earth are typically static

135 under relevant timescales. Therefore, it is necessary to characterize environments

136 with similar geologic characteristics but different degrees of aridity for

137 comparison. In this way, we can identify and differentiate the critical processes in

138 these regions and potentially relate soil geochemistry to various martian epochs.

139 The Moroccan desert has previously been proposed as Mars-relevant for

140 operations testing (Ori et al., 2011). Here, we examine the northern Tindouf

141 basin in southeastern Morocco as a region suitable for use as an analog for soil

142 chemistry and aqueous geochemistry across different martian epochs. 


\section{Materials and Methods}

\section{2.1. Climate and Geology of Sample Site}

146 The study region is located on the northern edge of the Tindouf basin, in the

147 strewn field from which the Tissint Mars meteorite fragments were recovered.

148 The site is located between the El Aglâb mountains to the north and the Hamada

149 Du Drâa desert to the south, near the El Ga'ïdat plateau (centered within a $\sim 6 \mathrm{~km}$

150 radius around $29^{\circ} 29^{\prime} 41.29^{\prime \prime} \mathrm{N}, 07^{\circ} 34^{\prime} 50.50^{\prime \prime} \mathrm{W}$ ) (Aoudjehane et al., 2012) (Fig. 1).

151 Broadly speaking, the environment is an inland desert ( $220 \mathrm{~km}$ inland) free of

152 any evaporitic and sabkha features. The basin, located in the foothills on the

153 southern margin of the Atlas Mountains, feeds into the Draa River (Oued Draa)

154 watershed, which is dry most of the year at this location, consistent with the

155 present day climate of a warm arid desert (Peel et al., 2007). The Tindouf basin

156 contains approximately an $8 \mathrm{~km}$ thick base layer of Cambrian to Carboniferous

157 marine sediment with approximately $100 \mathrm{~m}$ of Pliocene soils deriving from the

158 Atlas Mountains above it (Selley, 1997) and atmospheric input (this study). The

159 study area is near the border with Algeria, and lies entirely within a restricted-

160 accessed zone controlled by the Moroccan military. The area is uninhabited and

161 historically only used for military patrols along well-defined $4 \times 4$ tracks, although

162 it has recently experienced substantial foot traffic by Bedouins seeking fragments

163 of the Tissint meteorite. 
164 We divided the study site into two geographically distinct, but physically

165 proximate regions in order to evaluate the influence of the landform variations on

166 the soluble chemistry of the soils. The Ga'idat region is located at the southern

167 edge of the site at an average elevation of $400 \pm 15 \mathrm{~m}$ and consists of a plateau

168 exhibiting little fluvial influence with stable well-developed surface features. The

169 Aglâb region is located at the northern edge of the study site at the base of a

170 mountain with an average elevation of $380 \pm 0.5 \mathrm{~m}$. The Aglâb region is

171 characterized by alluvial fans, dry river beds, and variable topography indicative

172 ephemeral streams and other fluvial processes temporarily feeding the River Draa.

173 2.2. Sampling Procedures

174 Soil samples were collected from six sites (at 11 pits) in the Aglâb region and

175 from six sites (at 9 pits) in the Ga'ïdat region (Fig. 1). Sampling sites were

176 chosen in flat surfaced areas at local topographic highs, without vegetation or foot

177 tracks, generally with loose to consolidated desert pavement. At each sampling

178 site two shallow pits were dug to a depth of $20 \mathrm{~cm}$; one at a location in which the

179 soil was covered with desert pavement, and a second at a similar location nearby

180 without substantial pavement (Fig. 2). At each site, any surface cobbles were

181 removed, and a "surface" soil/silt sample from 0-5 cm, and a "depth" sample from

$182 \quad 15-20 \mathrm{~cm}$ were collected and sealed in pre-sterilized Whirl-Pak ${ }^{\circledR}$ sample bags.

183 The sampling depth was chosen as a layer of caliche was encountered in most 
184 areas beginning at $20-30 \mathrm{~cm}$. This was repeated throughout the sampling field to

185 obtain a well-represented coverage of the area.

\subsection{Soluble Content Analysis}

187 Soil samples were returned to the laboratory and split into sand (2 mm-75

$188 \mu \mathrm{m})$ and fine $(<75 \mu \mathrm{m})$ fractions prior to leaching. A $1.0 \mathrm{~g}$ portion of both

189 fractions of each sample was leached at a 1:10 soil:water ratio for 1 hour with

190 rocking on a Thermoline Labquake and an aliquot of each leachate was then

191 diluted to a conductivity of $50 \mu \mathrm{S} / \mathrm{cm}$. The undiluted samples were analyzed for

192 perchlorate $\left(\mathrm{ClO}_{4}{ }^{-}\right)$and the diluted samples for inorganic anions by ion

193 chromatography using a Dionex ICS2000 under the conditions listed in Table 1.

194 Final concentrations for soil samples were determined by accounting for dilutions

195 and summing the resulting concentrations, weighted by their compositional

196 percentage.

\section{2.4. Comparative Studies}

198 Ionic concentration of samples from this study were compared to soils in five

199 other terrestrial sites of differing aridity and temperature, as well as leachate of

200 the Mars meteorite EETA79001, and the in-situ Mars soil analyses performed by

201 the Wet Chemistry Laboratory (WCL) on board the Mars Phoenix Lander. The

202 soluble ionic distributions in these regions are compared in terms of the

203 differences between preservation potential in these locales, with speculative links

204 to soil geochemistry in different Martian epochs. 
206 3. Results

207 The measured anion content of the soil for the Aglâb and Ga’ïdat sampling

208 regions is shown in Table 2. In both regions the particle size distributions

209 generally consist of a primarily sandy soil with a tendency for fine grained

210 particles to accumulate on the surface. The average particle distributions for

211 depth and surface samples are 90-95 wt $\%$ and $75-90 \mathrm{wt} \%$ sand particles

212 respectively. A neutral soil $\mathrm{pH}$ is observed across the entire study region with an

213 average $\mathrm{pH}$ of $7.1 \pm 0.5$ across all samples and differences between surface and

214 subsurface $\mathrm{pH}$ values ranging from $0.3-2 \%$. The electrical conductivity (EC) is

215 less consistent across samples with the RSD values ranging from $130-200 \%$ both

216 within and across regions, suggesting a heterogeneous distribution of salts,

217 consistent with variability in our ionic measurements. The EC and $\mathrm{pH}$ values for

218 each pit at each site are listed in Table 3. The ionic concentrations are generally

219 higher at depth than at the surface (Table 2). This is especially notable for

220 perchlorate which is below the limit of detection (LOD) of $2.5 \times 10^{-4} \mathrm{mmol} / \mathrm{kg}$ in

221 surface samples, but present at up to $2.5 \times 10^{-3} \mathrm{mmol} / \mathrm{kg}(250 \mathrm{ppb})$ at $20 \mathrm{~cm}$.

222 The relative distribution of oxyanions is used to assess the differences

223 between regions by normalizing against total measured anionic content. This

224 allows for the comparison of the relative distribution patterns between samples

225 without the confounding influence of variable salinity due to differential 
226 preservation and transport. Fig. 3 shows the interquartile range (IQR) for the

227 distribution of anions, normalized against the total measured anionic content.

228 Chloride molar fractions exhibit the greatest variability within sampling regions,

229 and nitrate the smallest. However, nitrate molar fractions exhibit the largest

230 difference between samples sites, with a $72 \%$ difference in medians and a $39 \%$

231 difference in the IQR between the Aglâb and Ga'idat regions. This is compared

232 to a $48 \%$ and $2 \%$ difference in median and IQR for chloride and a $2 \%$ and $7 \%$

233 difference in median and IQR for sulfate. Surface and depth molar fractions tend

234 to be more consistent between the ions with the median difference of $25 \%, 10 \%$,

235 and $23 \%$ for chloride, sulfate, and nitrate, respectively, while IQR values differed

236 by $20 \%, 20 \%$, and $15 \%$, respectively. However, differences in IQR for all ions

237 and the difference in median for sulfate, are greater between surface and depth

238 samples, than between sampling regions. Fig. 4 shows the relationship between

239 the concentrations of oxyanions (sulfate, nitrate, and perchlorate) and the chloride

240 for the Moroccan soil samples from this study.

\section{4. Discussion}

243 The relatively similar normalized ionic ratios observed throughout the two

244 sampling regions can be summarized as an overall similarity in terms of salt

245 origin, resulting in a geochemically homogenous area with outlier sample 
246 variations due to disparate localized transport processes. This is supported by a

247 greater difference in the more soluble nitrate and chloride ions than sulfate, which

248 would result from the distribution of these highly soluble anions in response to

249 intermittent precipitation events and diurnal condensation.

250 The difference in the concentrations between the surface and the subsurface

251 samples is larger than for the samples from the two regions. This is likely the

252 result of differences in the availability of water to percolate through the soil and

253 ubiquitous surface mixing by aeolian processes. The higher elevation, better

254 developed soil profiles on the Ga'ïdat plateau are generally less susceptible to

255 variation, as evidenced by smaller relative standard deviations in both surface and

256 depth conductivity measurements, likely due to the limited transport processes

257 occurring in the region. On the other hand, the more complex Aglâb region, with

258 its input from aqueous discharge from the nearby mountain and channeling from

259 the surrounding areas in response to the surrounding higher elevation landforms,

260 results in greater variation depending on sampling location. Geomorphological

261 differences aside, the regions can be reasonably considered to be the same in

262 terms of their normalized soluble anion content and are treated as such for further

263 comparison purposes.

264 Perchlorate is one the most soluble naturally-occurring salts, so its presence

265 near the surface implies either an extreme lack of rainfall, or a barrier to vertical

266 diffusion. At the hyper-arid core of the Atacama Desert, where rainfall averages 
267 less than $1 \mathrm{~mm} \mathrm{yr}^{-1}$ (McKay et al. 2003), perchlorate is generally leached from

268 soil profiles to at least $50 \mathrm{~cm}$ depth (Jackson et al. 2015), presumably via

269 exceedingly rare large rainfall events. In the Tindouf, significant rainfall events

270 are typical in the winter months, thus we hypothesize the sporadic perchlorate

271 abundances observed at $15-20 \mathrm{~cm}$ depth (from LOD to $2.5 \times 10^{-3} \mathrm{mmol} / \mathrm{kg}$ ), reflect

272 a localized hydrological control dominated by a vertical barrier at the hardpan

273 caliche. In addition to plant uptake (which does not apply to our sample sites),

274 local geomorphological effects have been shown to cause similar heterogeneity in

275 the Armargosa desert (Andraski et al. 2014). There, measured perchlorate

276 deposition fluxes of $3.4 \mathrm{ng} \mathrm{cm}^{-2} \mathrm{y}^{-1}$ agree with higher-end theoretical predictions

277 of atmospheric perchlorate production from the Atacama desert (Catling et al.

278 2010). Assuming these perchlorate production rates apply to the Tindouf, this

279 yields an $\sim 10^{3}$ year accumulation time for the $2.5 \times 10^{-3} \mathrm{mmol} / \mathrm{kg}$ observed at 20

$280 \mathrm{~cm}$ depth. We speculate that the caliche layer plays a role in the concentration of

281 soil anions, absorbing moisture from significant rainfall events followed by

282 extreme evaporation, and that only very significant rainfall years would flush out

283 the entire system into the Draa River.

\subsection{Comparison with Other Proposed Mars Analog Sites}

286 On Earth, nitrate, chloride, and perchlorate in arid and semi-arid soils are

287 known to be primarily of atmospheric origin (Michalski et al., 2004 ; Bao et al., 
288 2004). These ions are also highly water soluble and tend to accumulate in arid 289 and semi-arid environments (Walvoord et al., 2003 ; Jackson et al., 2015). As a

290 result, the ratio of these ions in desert soils can be used in the interpretation of the

291 aqueous processes in these areas. Fig. 5 shows the correlation between the

292 concentrations of oxyanions and chloride concentrations for sulfate, nitrate, and

293 perchlorate, for samples from Morocco (linear fit lines from Fig. 4) compared to

294 samples, from five terrestrial Mars analog sites (Stroble et al., 2013; Tamppari et

295 al., 2012), the Mars meteorite EETA790001 (Kounaves et al., 2014), and the

296 Mars Phoenix WCL analyses (Kounaves et al., 2010).

297 4.1.1. Atacama. Samples from the Atacama are similar to Morocco in their

$298 \mathrm{NO}_{3} / \mathrm{Cl}$ ratios and correlation (Fig. 5a), but differ in their $\mathrm{NO}_{3} / \mathrm{ClO}_{4}$ ratio (Fig. 7)

299 which is lower than in Morocco. The prolonged hyper-arid conditions in the

300 Atacama compared to Morocco may explain the lower $\mathrm{NO}_{3} / \mathrm{ClO}_{4}$ ratio observed in

301 the Atacama. Since $\mathrm{ClO}_{4}{ }^{-}$is highly soluble and is quickly transported in the

302 presence of water, the prolonged hyper-arid conditions in this region would result

303 in the greater accumulation of $\mathrm{ClO}_{4}{ }^{-}$, reducing the $\mathrm{NO}_{3} / \mathrm{ClO}_{4}$ ratio.

304 4.1.2. Beacon Valley. The Beacon Valley samples have comparable $\mathrm{NO}_{3} / \mathrm{Cl}$

305 and $\mathrm{SO}_{4} / \mathrm{Cl}$ ratios to those observed in the Moroccan samples (Fig. 5b). However,

306 the correlations in both cases demonstrate a greater increase in oxyanion species

307 compared with $\mathrm{Cl}^{-}$in Beacon Valley. This consistently larger relative increase

308 associated with samples from Beacon Valley indicate a preference for 
309 accumulation of oxyanions compared to chloride. This may be due to the higher

310 elevation of Beacon Valley which results in less input of $\mathrm{Cl}^{-}$from ocean spray

311 and/or a more rapid accumulation of atmospherically derived oxyanion species.

312 Both $\mathrm{NO}_{3}{ }^{-}$and $\mathrm{ClO}_{4}{ }^{-}$are highly soluble, and their persistence in an environment is

313 indicative of the relative absence of aqueous transport processes. The correlation

314 between $\mathrm{NO}_{3}{ }^{-}, \mathrm{ClO}_{4}^{-}$, and $\mathrm{Cl}$ for Beacon Valley falls in the center when compared

315 with the other investigated analog environments (Figs 6 and 7) suggesting that

316 Beacon Valley is an intermediate in terms of the processes driving ionic ratios in

317 these areas.

318 4.1.3. University Valley. The University Valley $\mathrm{NO}_{3} / \mathrm{ClO}_{4}$ ratios are the

319 most similar to the Morocco samples (Fig. 7), but no other similarities are

320 observed between the data sets. In general, oxyanion ratios and correlations are

321 much larger and steeper in University Valley than other analog sites (Fig. 5c).

322 This is similar to the observations for Beacon Valley, wherein oxyanions

323 accumulate and $\mathrm{Cl}^{-}$input is minimal, but extended to a more arid environment.

324 4.1.4. Taylor Valley. For Taylor Valley the $\mathrm{NO}_{3}{ }^{-}$is well correlated with $\mathrm{Cl}^{-}$

$325\left(R^{2}=0.90\right)$ with a comparable slope to that observed in the Moroccan samples,

326 but is relatively depleted in $\mathrm{NO}_{3}{ }^{-}$with respect to $\mathrm{Cl}^{-}$(Fig. 5d). $\mathrm{NO}_{3}{ }^{-}$is similarly

327 well correlated to $\mathrm{ClO}_{4}^{-}\left(R^{2}=0.85\right)$ with the shallowest slope observed across all

328 investigated analog sites (Fig. 6), and a two order of magnitude shallower slope

329 than is observed in Morocco. In general, Oxyanion/ $\mathrm{Cl}$ ratios are lower and 
330 oxyanions tend to accumulate less compared to $\mathrm{Cl}^{-}$in Taylor Valley than in

331 Morocco, with the exception of an enrichment of $\mathrm{ClO}_{4}{ }^{-}$relative to $\mathrm{Cl}^{-}$. This may

332 be the result of an increase in $\mathrm{Cl}^{-}$compared with $\mathrm{NO}_{3}{ }^{-}$in Taylor Valley, as a result

333 of input from ocean water spray.

334 4.1.5. Victoria Valley. The Victoria Valley samples are the most similar of

335 the investigated sites to the Moroccan samples (Fig. 5e). Specifically, comparable

336 ratios are observed between the regions for $\mathrm{NO}_{3} / \mathrm{Cl}$ and $\mathrm{NO}_{3} / \mathrm{ClO}_{4}$ (Fig. 7).

337 However, while $\mathrm{NO}_{3} / \mathrm{ClO}_{4}$ ratios exhibit a similar correlation between the regions,

338 Victoria Valley has an order of magnitude steeper slope in $\mathrm{NO}_{3} / \mathrm{Cl}$ correlation

339 compared with Morocco. The similarity in ratios, but difference in linear fit for

340 Victoria Valley samples is likely related to differences in post-depositional

341 processes such as aqueous transport, which may be more complicated in Victoria

342 Valley compared with Morocco in part due to influences from shallow

343 groundwater and permafrost in this polar region (Levy et al, 2011; Marchant and

344 Head, 2007).

\section{4.2. Comparison to Direct Measurements on Mars Samples}

346 Figure $5 \mathrm{f}$ shows our results in comparison with two direct measurements of

347 soluble species in martian samples, one from the in-situ WCL analyses of martian

348 soil by the Phoenix Mars Lander (Kounaves et al., 2010) and the other from a

349 carbonate clast in the Mars meteorite EETA79001 (Kounaves et al., 2014). In

350 general, oxyanion species are more concentrated in both the WCL and 
351 EETA79001 samples, while $\mathrm{Cl}^{-}$is depleted. Of note is the similarity between the

352 relative $\mathrm{SO}_{4}{ }^{2-}, \mathrm{NO}_{3}{ }^{-}$, and $\mathrm{ClO}_{4}{ }^{-}$values in EETA79001 measurements compared to

353 the Moroccan samples. In general, it is observed that $\mathrm{SO}_{4} / \mathrm{Cl}, \mathrm{NO}_{3} / \mathrm{Cl}$ and

$354 \mathrm{ClO}_{4} / \mathrm{Cl}$ ratios are consistently and similarly higher in EETA79001. Also, of note

355 is the large concentration of $\mathrm{ClO}_{4}{ }^{-}$that was measured by the Phoenix WCL

356 compared to EETA79001. This may be indicative of a steady increase in $\mathrm{ClO}_{4}{ }^{-}$

357 concentration over time as $\mathrm{Cl}^{-}$has been shown to be easily oxidized to $\mathrm{ClO}_{4}{ }^{-}$on

358 mineral surfaces (Carrier and Kounaves, 2015). A similar tendency is noted in

359 the analog sites wherein $\mathrm{ClO}_{4} / \mathrm{Cl}$ ratios increase with increasing aridity. This

360 observation supports the proposition that the higher aridity locales such as

361 University Valley can serve as analogs to more recent martian epochs while the

362 less arid Victoria Valley would serve as an analog to earlier epochs.

363 4.3. Comparison to The Martian Epochs

364 A summary of the martian epochs and their proposed corresponding

365 terrestrial analogs are shown in Fig. 8. If we consider the MDV as analogs to the

366 different martian epochs depending on the extent of aqueous influence, we find

367 that it decreases in the order University Valley $>$ Beacon Valley $>$ Victoria Valley

$368>$ Taylor Valley. In this way, University and Beacon Valley can be roughly

369 considered as analogs to the Amazonian/Hesperian epochs, and Taylor and

370 Victoria Valleys to the Hesparian/Noachian epochs. Due to the greater

371 similarities between the lower elevation Victoria Valley and the Moroccan 
372 samples as compared to the higher elevation University Valley samples, and the

373 likelihood that these similarities are the result of the greater influence of aqueous

374 processes in these regions, we argue that the Moroccan sample locations are

375 potential soil geochemistry analogs to the late Noachian epoch on Mars.

\section{5. Conclusions}

377 The utility of the Tindouf Basin region of southeastern Morocco as a more

378 accessible analog with a similar soil geochemistry to the MDVs is demonstrated

379 by the relative similarity of the distribution of ionic species between the

380 Moroccan samples and other Mars analog sites. In general, samples from this

381 region of Morocco show the greatest similarity with samples from Victoria

382 Valley, Beacon Valley and the Atacama. Moroccan samples are consistently

383 depleted in oxyanion species compared to University Valley and enriched

384 compared with Taylor Valley. Specifically, $\mathrm{NO}_{3} / \mathrm{Cl}$ ratios are comparable to

385 many proposed Mars analog sites, with the strongest similarities observed with

386 Victoria Valley and Atacama samples. The $\mathrm{SO}_{4} / \mathrm{Cl}$ ratios are likewise similar to

387 those from Beacon Valley, Victoria Valley, and in the Atacama. While

388 perchlorate values in Morocco are typically lower than other analog sites,

389 conditions in the region are sufficiently arid to retain oxychlorines at detectable

390 levels. Processes that may have preferentially increased the perchlorate in other

391 regions could include rapid aqueous accumulation and evaporation of the highly

392 soluble oxychlorines, or the production by direct UV oxidation of chlorine in 
393 chloride-bearing minerals, as has been suggested to occur on Mars (Carrier and

394 Kounaves, 2015). The perchlorate in the Morocco samples is most likely a result

395 of slow accumulation via atmospheric production as occurs over most of the Earth

396 (Catling et al., 2010) though direct UV oxidation cannot be entirely ruled out.

\section{Acknowledgements}

398 We would like to thank Joseph Levy and the anonymous reviewers who helped

399 improve this manuscript. We also thank the Ibn Battuta Centre in particular Gian

400 Gabrile Ori and Kamal Taj-Edine for their assistance with logistics and fieldwork.

401 In addition, we would like to thank the Moroccan military for access as well as

402 Aubrey Zerkle and Gordon Fontaine for their assistance in the field.

\section{Disclosure Statement}

404 No competing financial interests exist.

406 References

407 Andraski, B. J., W. A. Jackson, T. L. Welborn, J. K. Böhlke, R. Sevanthi, and

408 D.A. Stonestrom. (2014) Soil, Plant, and Terrain Effects on Natural

409 Perchlorate Distribution in a Desert Landscape. J. Environ. Qual. 43:980-994

410

411 Aoudjehane, H.C., Avice, G., Barrat, J-A., Boudouma, O., Chen, G., Duke, M.J.

412 M., Franchi, I.A., Gattacceca. J., Grady, M.M., Greenwood, R.C., Herd, 
Submitted to Astrobiology (Special Issue)

413

414

415

416

417

418

419

420

421

422

423

424

425

426

427

428

429

430

431

432

C.D.K., Hewins, R., Jambon, A., Marty, B., Rochette, P., Smith, C.L.,

Sautter, V., Verchovsky, A., Weber, P., and Zanda, B. (2012) Tissint

Martian Meteorite: A Fresh Look at the Interior, Surface, and Atmosphere of Mars. Science 338:785-788.

Arvidson, R.E., Squyres, S.W., Bell, J.F., Catalano, J.G., Clark, B.C., Crumpler, L.S., de Souza, P.A., Fairén, A.G., Farrand, W.H., Fox, V.K., Gellert, R., Ghosh, A., Golombek, M.P., Grotzinger, J.P., Guinness, E.A., Herkenhoff, K.E., Jolliff, B.L., Knoll, A.H., Li, R., McLennan, S.M., Ming, D.W., Mittlefehldt, D.W., Moore, J.M., Morris, R.V., Murchie, S.L., Parker ,T.J., Paulsen, G, Rice, J.W., Ruff, S.W., Smith, M.D., and Wolff, M. J. (2014) Ancient Aqueous Environments at Endeavour Crater, Mars. Science 343 (6169): 1248097.

Azua-Bustos, A., Caro-Lara, L., and Vicuna, R. (2015) Discovery and Microbial Content of the Driest Site of the Hyperarid Atacama Desert, Chile. Environ. Microbio.Rep. 7:388-394.

Bao H., Jenkins K.A., Khachaturyan M., and Díaz G.C. (2004) Different sulfate sources and their post-depositional migration in Atacama soils. Earth Planet. Sci. Lett. 224:577-587.

Bao H., and Gu B. (2004) Natural Perchlorate Has a Unique Oxygen Isotope Signature. Environ. Sci. Technol., 38:5073-5077. 
433 Bibring J.P., Langevin Y., Mustard J.F., Poulet F., Arvidson R., Gendrin A., 434 Gondet B., Mangold N., Pinet P., Forget F., Berthe M., Bibring J.P., Gendrin 435 A., Gomez C., Gondet B., Jouglet D., Poulet F., Soufflot A., Vincendon M., 436 Combes M., Drossart P., Encrenaz T., Fouchet T., Merchiorri R., Belluci G., 437 Altieri F., Formisano V., Capaccioni F., Cerroni P., Coradini A., Fonti S., 438 Korablev O., Kottsov V., Ignatiev N., Moroz V., Titov D., Zasova L., 439 Loiseau D., Mangold N., Pinet P., Doute S., Schmitt B., Sotin C., Hauber E., 440 Hoffmann H., Jaumann R., Keller U., Arvidson R., Mustard J.F., Duxbury 441 T., Forget F., and Neukum G. (2006) Global mineralogical and aqueous mars 442 history derived from OMEGA/Mars Express data. Science, 312:400-4.

443 Carrier B.L., and Kounaves S.P. (2015) The origins of perchlorate in the Martian $444 \quad$ soil. Geophys. Res. Lett. 42:3739-3745.

445 Cary, J.W., Papendick, R.I., and Campbell, G.S. (1979) Water and Salt Movement 446 in Unsaturated Frozen Soil: Principles and Field Observations. Soil Sci. Soc. $447 \quad$ Am. J. 43:3-8.

448 Catling D.C., Claire M.W., Zahnle K.J., Quinn R.C., Clark B.C., Hecht M.H., and 449 Kounaves S. (2010) Atmospheric origins of perchlorate on Mars and in the $450 \quad$ Atacama. J. Geophys. Res. 115:E00E11.

451 Claridge, G.G.C., and Campbell, I.B. (1977) The salts in Antarctic soils, their 452 distribution and relationship to soil processes. Soil Science, 123:377-384. 
Submitted to Astrobiology (Special Issue)

453 Dickinson, W.W., and Rosen, M.R. (2003) Antarctic Permafrost: An Analogue

454 for Water and Diagenetic Minerals on Mars. Geology 31:199-202.

455 Ehlmann, B.L., Berger, G., Mangold, N., Michalski, J.R., Catling, D.C., Ruff,

456 S.W., Chassefière, E., Niles, P.B., Chevrier, V., and Poulet, F. (2013)

457 Geochemical Consequences of Widespread Clay Mineral Formation in Mars'

$458 \quad$ Ancient Crust. Space Sci. Rev. 174:329-364.

459 Ewing, S.A., Sutter, B., Owen, J., Nishiizumi, K., Sharp, W., Cliff, S.S., Perry,

460 K., Dietrich, W., McKay, C.P., and Amundson, R. (2006) A threshold in soil

461 formation at Earth's arid-hyperarid transition. Geochim. Cosmochim. Acta,

$462 \quad 70: 5293-5322$.

463 Hartley, A.J., Chong, G., Houston, J., and Mather, A.E. (2005) 150 Million Years

464 of Climatic Stability: Evidence from the Atacama Desert, Northern Chile. $J$.

$465 \quad$ Geol. Soc. 162:421-424.

466 Jackson, W.A., Davila, A.F., Böhlke, J.K., Sturchio, N.C., Sevanthi, R., Estrada,

467 N., Brundrett, M., Lacelle, D., McKay, C.P., Poghosyan, A., Pollard, W., and

468 Zacny, K. (2016) Deposition, accumulation, and alteration of $\mathrm{Cl}^{-}, \mathrm{NO}_{3}{ }^{-}$,

$469 \mathrm{ClO}_{4}{ }^{-}$and $\mathrm{ClO}_{3}{ }^{-}$salts in a hyper-arid polar environment: Mass balance and

$470 \quad$ isotopic constraints. Geochim. Cosmochim. Acta 182:197-215.

471 Jackson, W.A., Böhlke, J. K., Andraski, B. J., Fahlquist, L., Bexfield, L., Eckardt, 472 F.D., Gates, J.B., Davila, A.F., McKay, C.P., Rao, B., Sevanthi, R., 
Orris, G., Betancourt, J., Stonestrom, D., Latorre, C., Li, Y., and Harvey,

G.J. (2015) Global patterns and environmental controls of perchlorate and nitrate co-occurrence in arid and semi-arid environments. Geochim. Cosmochim. Acta 164:502-522.

Jackson, W.A., Anderson, T.A., Tian, K., and Tock, R.W. (2005) The Origin of 479 Naturally Occurring Perchlorate : The Role of Atmospheric Processes. $480 \quad$ Environ. Sci. 39:1569-1575.

481 Jordan, T.E., Kirk-Lawlor, N.E., Blanco, P.N., Rech, J.A., and Cosentino, N.J.

482 (2014) Landscape Modification in Response to Repeated Onset of Hyperarid 483 Paleoclimate States since 14 Ma, Atacama Desert, Chile. Bull. Geol. Soc. Am. 126:1016-1046.

Keys J.R., and Williams K. (1981) Origin of crystalline, cold desert salts in the McMurdo region, Antarctica. Geochim. Cosmochim. Acta 45:2299-2309.

Kounaves, S.P., Hecht, M.H., Kapit, J., Gospodinova, K., DeFlores, L., Quinn, 488 R.C., Boynton, W.V., Clark, B.C., Catling, D.C., Hredzak, P., Ming, D.W., 
Submitted to Astrobiology (Special Issue)

493

494

495

496

497

498

499

500

501

502

503

504

505

506

507

508

509

510

511 Marchant, D.R., and Head, J.W. (2007) Antarctic dry valleys: Microclimate

512

(2014) Evidence of martian perchlorate, chlorate, and nitrate in Mars meteorite EETA79001: Implications for oxidants and organics. Icarus, 229:206-213.

Langevin. Y., Poulet. F., Bibring. J.-P., and Gondet. B. (2005) Sulfates in the North Polar Region of Mars Detected by OMEGA/Mars Express. Science, 307:1584-1586.

Laskar, J., A. C. M. Correia, M. Gastineau, F. Joutel, B. Levrard, and P. Robutel (2004), Long term evolution and chaotic diffusion of the insolation quantities of Mars, Icarus, 170:343-364.

Levy J.S., Fountain A.G., Gooseff M.N., Welch K.A., and Lyons W.B. (2011) Water tracks and permafrost in Taylor Valley, Antarctica: Extensive and shallow groundwater connectivity in a cold desert ecosystem. Geological Society of America Bulletin, 123:2295-2311.

Mahaney, W. (2001) Morphogenesis of Antarctic Paleosols: Martian Analogue. Icarus, 154:113-130.

Mangold, N., Carter, J., Poulet, F., Dehouck, E., Ansan, V., and Loizeau, D. (2012) Late Hesperian Aqueous Alteration at Majuro Crater, Mars. Planet. Space Sci. 72:18-30. 
climate change on Mars. Icarus, 192:187-222.

514 McKay C.P., Friedmann E.I., Gómez-Silva B., Cáceres-Villanueva L., Andersen

515 D.T., and Landheim R. (2003) Temperature and Moisture Conditions for

516 Life in the Extreme Arid Region of the Atacama Desert: Four Years of

517 Observations Including the El Niño of 1997-1998. Astrobiology, 3:393-406.

518 McLennan, S.M., Bell, S.F., Calvin, W.M., Christensen, P.R., Clark, B.C., de

519 Souza, P.A., Farmer, J., Farrand, W.H., Fike, D.A., Gellert, R., Ghosh, A.,

520 Glotch, T.D., Grotzinger, J.P., Hahn, B., Herkenhoff, K.E., Hurowitz, J.A.,

521 Johnson, J.R., Johnson, S.S., Jolliff, B., Klingelhofer, G., Knoll, A.H.,

522 Learner, Z., Malin. M.C., McSween, Jr H.Y., Pocock, J., Ruff, S.W.,

523 Soderblom, L.A., Squyres, S.W., Tosca, N.J., Watters, W.A., Wyatt, M., and

524 Yen, A. (2005) Provenance and Diagenesis of the Evaporite-Bearing Burns

525 Formation, Meridiani Planum, Mars. Earth Planet. Sci. Lett. 240:95-121.

526 Michalski, G., Böhlke, J.K., and Thiemens, M. (2004) Long term atmospheric

527 deposition as the source of nitrate and other salts in the Atacama Desert,

528 Chile: New evidence from mass-independent oxygen isotopic compositions.

529 Geochim. Cosmochim. Acta, 68:4023-4038.

530 Navarro-González, R., Rainey, F.A., Molina, P., Bagaley, D.R., Hollen, B.J., de la

531 Rosa, J., Small, A.M., Quinn, R.C., Grunthaner, F.J., Cáceres, L., Gomez-

532 Silva, B., and McKay, C.P. (2003) Mars-Like Soils in the Atacama Desert, 
Submitted to Astrobiology (Special Issue)

533

534

535

536

537

538

539

540

541

542

543

544

545

546

547

548

549

550

551

552

Chile, and the Dry Limit of Microbial Life. Science, 302:1018-1021.

Ori, G.G., Taj-Eddine, K., and Dell'Arciprete, I. (2011) The Ibn Battuta Centre (Marrakech, Morocco) for Testing Lander Science, Operations and Landing Systems, in Analogue Sites for Mars Missions: MSL and Beyond, LPI Contribution No. 161, Abstract 6006.

Peel, M.C., Finlayson, B.L., and McMahon, T.A. (2007) Updated World Map of Köppen-Geiger Climate Classification. Hydrol. Earth Sys. Sci. 11:1633-44.

Selley, R.C. (1997) Chapter 1 The Sedimentary Basins of Northwest Africa, In Sedimentary Basins of the World Vol. 3: African Basins, 3-16.

Stroble, S.T., McElhoney, K.M., and Kounaves, S.P. (2013) Comparison of the Phoenix Mars Lander WCL soil analyses with Antarctic Dry Valley soils, Mars meteorite EETA79001 sawdust, and a Mars simulant. Icarus, 225:933939.

Tamppari, L.K., Anderson, R.M., Archer, P.D., Douglas, S., Kounaves, S.P., McKay, C.P., Ming, D.W., Moore, Q., Quinn, J.E., Smith, P.H., Stroble, S., and Zent, A.P. (2012) Effects of extreme cold and aridity on soils and habitability: McMurdo Dry Valleys as an analogue for the Mars Phoenix landing site. Antarctic Science, 24:211-228.

Toner, J.D., Sletten, R.S., and Prentice, M.L. (2013) Soluble salt accumulations in Taylor Valley, Antarctica: Implications for paleolakes and Ross Sea Ice 
554 Toon, O.B., Pollack, J.B., Ward, W., Burns, J.A., and Bilski, K. (1980) The Astronomical Theory of Climatic Change on Mars. Icarus 44:552-607.

556 Touma, J, and Wisdom, J. (1993) The Chaotic Obliquity of Mars. Science $557 \quad 259: 1294-1297$.

558 Walvoord M.A., Phillips F.M., Stonestrom D.A., Evans R.D., Hartsough P.C.,

559 Newman B.D., and Striegl R.G. (2003) A Reservoir of Nitrate Beneath

$560 \quad$ Desert Soils. Science, 302:1021-1024.

561 Ward, W. (1973) Large-Scale Variations in the Obliquity of Mars. Science

$562 \quad 181: 260-262$.

563 Wray, J.J., Noe Dobrea, E.Z., Arvidson, R.E., Wiseman, S.M., Squyres, S.W., 564 McEwen, A.S., Mustard, J.F., and Murchie, S.L. (2009) Phyllosilicates and 565 sulfates at Endeavour Crater, Meridiani Planum, Mars. Geophys. Res. Lett., $566 \quad 36:$ L21201.

567 Zhu B., and Yang X. (2010) The origin and distribution of soluble salts in the 568 sand seas of northern China. Geomorphology, 123:232-242. 
Submitted to Astrobiology (Special Issue)

570 Table 1: Parameters and reagents used for IC analysis of samples. Columns used 571 for all samples were $250 \mathrm{~mm} \times 4 \mathrm{~mm}$

\begin{tabular}{|c|c|c|}
\hline & Anions & Perchlorate \\
\hline Dionex Column & $\mathrm{AS} 16$ & $\mathrm{AS} 18$ \\
\hline Eluent & $\mathrm{KOH}$ & $\mathrm{KOH}$ \\
\hline Eluent Conc., $\mathbf{m M}$ & 20 & 35 \\
\hline Flor Rate, $\mathbf{m L} / \mathbf{m i n}$ & 1 & 1.25 \\
\hline Suppressor Current, $\boldsymbol{\mu S}$ & 75 & 175 \\
\hline Injection Volumer, $\boldsymbol{\mu L}$ & 25 & 100 \\
\hline
\end{tabular}

572
573 
574 Table 2: Measured anion concentration data for the Aglâb and Ga'ïdat region 575 samples

\begin{tabular}{|c|c|c|c|c|c|c|}
\hline \multicolumn{7}{|c|}{ Surface $(0-5 \mathrm{~cm})$ lon Concentration $(\mathrm{mmol} / \mathrm{kg})$} \\
\hline Region & Sample & Chloride & Sulfate & Nitrate & Chlorate & Perchlorate \\
\hline \multirow{11}{*}{ Aglâb } & $1 \mathrm{a}$ & $3.42 \pm 0.123$ & $2.85 \pm 0.050$ & $0.57 \pm 0.050$ & $0.09 \pm 0.010$ & ND \\
\hline & $1 \mathrm{~b}$ & $5.63 \pm 0.052$ & $15.43 \pm 0.111$ & $1.06 \pm 0.084$ & $0.090 \pm 0.008$ & ND \\
\hline & $2 a$ & $2.34 \pm 0.045$ & $1.55 \pm 0.013$ & $0.38 \pm 0.015$ & $0.06 \pm 0.004$ & ND \\
\hline & $2 b$ & $2.55 \pm 0.008$ & $0.20 \pm 0.006$ & $0.26 \pm 0.005$ & $0.03 \pm 0.002$ & ND \\
\hline & $3 a$ & $0.87 \pm 0.023$ & $1.00 \pm 0.007$ & $0.45 \pm 0.009$ & $0.04 \pm 0.002$ & ND \\
\hline & $3 b$ & $0.45 \pm 0.005$ & $0.23 \pm 0.002$ & $0.34 \pm 0.002$ & $0.02 \pm 0.001$ & ND \\
\hline & $4 a$ & $44.52 \pm 0.395$ & $2.34 \pm 0.085$ & $4.69 \pm 0.112$ & $0.20 \pm 0.025$ & ND \\
\hline & $4 \mathrm{~b}$ & $282.47 \pm 1.687$ & $36.59 \pm 0.331$ & $1.45 \pm 0.203$ & ND & ND \\
\hline & $5 a$ & $26.51 \pm 0.073$ & $11.13 \pm 0.049$ & $0.87 \pm 0.021$ & $0.11 \pm 0.009$ & ND \\
\hline & $5 b$ & $23.97 \pm 0.096$ & $11.13 \pm 0.024$ & $1.54 \pm 0.042$ & $0.12 \pm 0.011$ & ND \\
\hline & $6 a$ & $1.68 \pm 0.148$ & $1.94 \pm 0.145$ & $0.37 \pm 0.027$ & ND & ND \\
\hline \multirow{9}{*}{ Ga'idat } & $7 a$ & $3.86 \pm 0.051$ & $0.72 \pm 0.012$ & $0.64 \pm 0.015$ & $0.06 \pm 0.004$ & ND \\
\hline & $7 \mathrm{~b}$ & $3.58 \pm 0.019$ & $0.14 \pm 0.002$ & $0.46 \pm 0.003$ & ND & ND \\
\hline & $8 a$ & $0.31 \pm 0.019$ & $0.32 \pm 0.005$ & $0.16 \pm 0.007$ & $0.03 \pm 0.001$ & ND \\
\hline & $9 a$ & $0.29 \pm 0.019$ & $0.22 \pm 0.006$ & $0.15 \pm 0.008$ & $0.04 \pm 0.003$ & ND \\
\hline & $10 a$ & $0.45 \pm 0.020$ & $0.28 \pm 0.007$ & $0.27 \pm 0.007$ & $0.03 \pm 0.002$ & ND \\
\hline & $11 a$ & $0.34 \pm 0.020$ & $0.30 \pm 0.008$ & $0.28 \pm 0.007$ & $0.05 \pm 0.002$ & ND \\
\hline & $11 \mathrm{~b}$ & $0.14 \pm 0.003$ & $0.13 \pm 0.002$ & $0.10 \pm 0.002$ & $0.03 \pm 0.001$ & ND \\
\hline & $12 a$ & $20.76 \pm 0.170$ & $1.97 \pm 0.045$ & $0.76 \pm 0.043$ & $0.09 \pm 0.013$ & ND \\
\hline & $12 \mathrm{~b}$ & $25.31 \pm 0.099$ & $1.96 \pm 0.017$ & $0.88 \pm 0.023$ & $0.10 \pm 0.010$ & ND \\
\hline \multicolumn{7}{|c|}{ Depth $(15-20 \mathrm{~cm})$ Ion Concentration $(\mathrm{mmol} / \mathrm{kg})$} \\
\hline Region & Sample & Chloride & Sulfate & Nitrate & Chlorate & Perchlorate \\
\hline \multirow{11}{*}{ Aglâb } & $1 \mathrm{a}$ & $102.89 \pm 8.882$ & $4.10 \pm 1.316$ & $11.96 \pm 1.071$ & ND & $4.7 \mathrm{E}-04 \pm 4.80 \mathrm{E}-05$ \\
\hline & $1 b$ & $14.86 \pm 0.128$ & $1.31 \pm 0.007$ & $1.17 \pm 0.019$ & $0.06 \pm 0.006$ & $2.56 \mathrm{E}-04 \pm 4.60 \mathrm{E}-05$ \\
\hline & $2 a$ & $131.89 \pm 2.542$ & $60.01 \pm 1.256$ & $11.70 \pm 0.389$ & ND & $5.04 \mathrm{E}-04 \pm 4.69 \mathrm{E}-05$ \\
\hline & $2 b$ & $87.41 \pm 1.781$ & $11.97 \pm 0.199$ & $13.23 \pm 0.175$ & ND & $5.20 \mathrm{E}-04 \pm 4.55 \mathrm{E}-05$ \\
\hline & $3 a$ & $2.67 \pm 0.087$ & $3.79 \pm 0.104$ & $1.26 \pm 0.032$ & $0.06 \pm 0.008$ & ND \\
\hline & $3 b$ & $0.18 \pm 0.004$ & $0.11 \pm 0.002$ & $0.11 \pm 0.003$ & $0.02 \pm 0.001$ & ND \\
\hline & $4 a$ & $89.09 \pm 62.724$ & $31.00 \pm 2.776$ & $27.87 \pm 15.474$ & ND & $1.28 \mathrm{E}-03 \pm 4.56 \mathrm{E}-05$ \\
\hline & $4 b$ & $1460.84 \pm 15.221$ & $231.30 \pm 1.165$ & $6.33 \pm 0.818$ & ND & ND \\
\hline & $5 a$ & $151.76 \pm 4.374$ & $55.72 \pm 1.091$ & $8.80 \pm 0.442$ & ND & $4.38 \mathrm{E}-04 \pm 1.23 \mathrm{E}-04$ \\
\hline & $5 b$ & $55.86 \pm 1.682$ & $37.58 \pm 1.562$ & $3.26 \pm 0.157$ & ND & ND \\
\hline & $6 a$ & $1.49 \pm 0.081$ & $6.70 \pm 0.032$ & $0.13 \pm 0.025$ & ND & ND \\
\hline \multirow{9}{*}{ Ga'idat } & $7 a$ & $15.03 \pm 0.384$ & $1.27 \pm 0.106$ & $4.57 \pm 0.260$ & ND & $2.50 \mathrm{E}-03 \pm 2.02 \mathrm{E}-05$ \\
\hline & $7 b$ & $165.20 \pm 1.366$ & $24.68 \pm 0.071$ & $24.65 \pm 0.094$ & ND & $4.25 \mathrm{E}-04 \pm 2.12 \mathrm{E}-05$ \\
\hline & $8 a$ & $3.17 \pm 0.081$ & $3.34 \pm 0.039$ & $1.60 \pm 0.034$ & $0.07 \pm 0.011$ & ND \\
\hline & $9 a$ & $21.75 \pm 0.583$ & $63.88 \pm 0.440$ & $7.79 \pm 0.241$ & ND & ND \\
\hline & $10 a$ & $11.08 \pm 0.206$ & $14.73 \pm 0.316$ & $6.14 \pm 0.123$ & ND & $2.72 \mathrm{E}-04 \pm 2.02 \mathrm{E}-05$ \\
\hline & $11 a$ & $2.71 \pm 0.064$ & $3.66 \pm 0.042$ & $1.49 \pm 0.026$ & $0.01 \pm 4.83 \mathrm{E}-04$ & ND \\
\hline & $11 \mathrm{~b}$ & $0.92 \pm 0.006$ & $1.03 \pm 0.005$ & $0.57 \pm 0.003$ & $0.03 \pm 0.001$ & ND \\
\hline & $12 a$ & $980.52 \pm 40.339$ & $163.47 \pm 10.130$ & $121.07 \pm 7.713$ & $0.56 \pm 0.148$ & $1.57 \mathrm{E}-03 \pm 3.35 \mathrm{E}-05$ \\
\hline & $12 \mathrm{~b}$ & $242.80 \pm 12.422$ & $12.85 \pm 0.628$ & $21.82 \pm 1.211$ & ND & $9.01 \mathrm{E}-04 \pm 4.94 \mathrm{E}-05$ \\
\hline
\end{tabular}


578 Table 3: $\mathrm{pH}$, conductivity, and grain size distribution data for the Aglâb and

579 Ga'ïdat region samples

580

\begin{tabular}{|c|c|c|c|c|c|c|c|c|c|}
\hline \multirow{2}{*}{ Region } & \multirow{2}{*}{ Sample } & \multicolumn{2}{|c|}{$\mathrm{pH}$} & \multicolumn{2}{|c|}{$\mathrm{EC}(\mu \mathrm{S} / \mathrm{cm})$} & \multicolumn{2}{|c|}{ 2000-75 $\mu \mathrm{m}$ (wt \%) } & \multicolumn{2}{|c|}{$<75 \mu \mathrm{m}$ (wt \%) } \\
\hline & & $0-5 \mathrm{~cm}$ & $15-20 \mathrm{~cm}$ & $0-5 \mathrm{~cm}$ & $15-20 \mathrm{~cm}$ & $0-5 \mathrm{~cm}$ & $15-20 \mathrm{~cm}$ & $0-5 \mathrm{~cm}$ & $15-20 \mathrm{~cm}$ \\
\hline \multirow{11}{*}{$\begin{array}{c}\text { Aglâb } \\
\text { samples }\end{array}$} & $1 \mathrm{a}$ & 6.96 & 6.87 & 146.51 & 1373.16 & $82.7 \%$ & $95.0 \%$ & $17.3 \%$ & $5.0 \%$ \\
\hline & $1 \mathrm{~b}$ & 7.64 & 7.68 & 480.07 & 243.56 & $87.4 \%$ & $90.0 \%$ & $12.6 \%$ & $10.0 \%$ \\
\hline & $2 a$ & 7.56 & 6.92 & 123.40 & 2487.04 & $74.8 \%$ & $96.0 \%$ & $25.2 \%$ & $4.0 \%$ \\
\hline & $2 b$ & 7.87 & 7.08 & 119.42 & 1374.29 & $86.9 \%$ & $90.7 \%$ & $13.1 \%$ & $9.3 \%$ \\
\hline & $3 a$ & 6.86 & 6.81 & 105.14 & 209.37 & $79.9 \%$ & $91.2 \%$ & $20.1 \%$ & $8.8 \%$ \\
\hline & $4 a$ & 7.34 & 6.63 & 594.49 & 7702.38 & $87.9 \%$ & $92.0 \%$ & $12.1 \%$ & $8.0 \%$ \\
\hline & $4 b$ & 8.04 & 7.12 & 4033.56 & 17484.78 & $92.2 \%$ & $92.3 \%$ & $7.8 \%$ & $7.7 \%$ \\
\hline & $5 a$ & 7.01 & 6.48 & 126.12 & 3178.29 & $84.6 \%$ & $94.1 \%$ & $15.4 \%$ & $5.9 \%$ \\
\hline & $5 b$ & 6.24 & 6.39 & 613.24 & 1418.46 & $81.6 \%$ & $92.5 \%$ & $18.4 \%$ & $7.5 \%$ \\
\hline & $6 a$ & 6.91 & 9.06 & 110.68 & 267.70 & $78.5 \%$ & $88.4 \%$ & $21.5 \%$ & $11.6 \%$ \\
\hline & average & $7.23 \pm 0.52$ & $7.12 \pm 0.74$ & $591.8 \pm 1160.6$ & $3253.1 \pm 5204.6$ & $84.5 \% \pm 5.7 \%$ & $92.4 \% \pm 2.3 \%$ & $15.5 \% \pm 5.7 \%$ & $7.6 \% \pm 2.3 \%$ \\
\hline \multirow{9}{*}{$\begin{array}{c}\text { Ga'ïdat } \\
\text { samples }\end{array}$} & $7 \mathrm{~b}$ & 7.25 & 6.90 & 98.16 & 955.86 & $87.7 \%$ & $93.2 \%$ & $12.3 \%$ & $6.8 \%$ \\
\hline & $8 a$ & 6.91 & 7.17 & 1077.74 & 346.78 & $73.9 \%$ & $90.2 \%$ & $26.1 \%$ & $9.8 \%$ \\
\hline & $9 a$ & 7.46 & 7.12 & 75.53 & 534.32 & $77.5 \%$ & $89.4 \%$ & $22.5 \%$ & $10.6 \%$ \\
\hline & $10 a$ & 7.45 & 7.33 & 59.55 & 199.91 & $74.2 \%$ & $90.1 \%$ & $25.8 \%$ & $9.9 \%$ \\
\hline & $11 a$ & 7.63 & 6.84 & 418.21 & 3330.37 & $84.4 \%$ & $91.9 \%$ & $15.6 \%$ & $8.1 \%$ \\
\hline & $11 \mathrm{~b}$ & 7.11 & 7.11 & 68.08 & 97.41 & $83.6 \%$ & $85.3 \%$ & $16.4 \%$ & $14.7 \%$ \\
\hline & $12 a$ & 6.44 & 6.34 & 540.50 & 2783.86 & $81.7 \%$ & $89.2 \%$ & $18.3 \%$ & $10.8 \%$ \\
\hline & $12 b$ & 7.72 & 6.87 & 508.47 & 3442.72 & $87.0 \%$ & $92.2 \%$ & $13.0 \%$ & $7.8 \%$ \\
\hline & average & $7.21 \pm 0.41$ & $6.97 \pm 0.29$ & $324.0 \pm 348.3$ & $1321.9 \pm 1430.8$ & $81.4 \% \pm 4.8 \%$ & $90.7 \% \pm 2.8 \%$ & $18.6 \% \pm 5.1 \%$ & $9.3 \% \pm 2.8 \%$ \\
\hline
\end{tabular}




\section{$583 \quad$ Figure Legends}

584 Figure 1: Sampling locations in the Tindouf Basin region in southeastern

585 Morocco.

586 Figure 2: Image showing the two locations where pits were dug, the first at a

587 location in which the soil was covered with desert pavement (foreground) and a

588 second one nearby without substantial pavement (upper left corner).

589 Figure 3: The interquartile range (IQR), normalized against the total measured

590 anionic content, for the distribution of (a) Nitrate, (b) Sulfate, and (c) Chloride

591 Figure 4: Logarithmic plot showing the linear correlation (line) of the

592 concentrations of sulfate (blue), nitrate (red), and perchlorate (green), with the

593 concentration of chloride for the Moroccan soil samples from this study.

594 Figure 5: Logarithmic plots of oxyanion vs chloride concentrations for sulfate

595 (blue), nitrate (red), and perchlorate (green), for samples from Morocco (linear fit

596 lines from Fig. 3) compared to samples, from (a) Atacama (b) Beacon Valley (c)

597 University Valley (d) Taylor Valley (e) Victoria Valley (f) Mars, (symbols).

598 Figure 6: Correlation of nitrate and perchlorate concentrations for all the Mars

599 analog sites in this study.

600 Figure 7: Correlation of $\mathrm{NO}_{3} / \mathrm{ClO}_{4}$ and $\mathrm{Cl} / \mathrm{NO}_{3}$ average ratios for each martian 601 analog site.

602 Figure 8: Proposed martian epochs most relevant to "Mars analog sites", based 603 on soil anion geochemistry and aridity . 
605 Figure 1

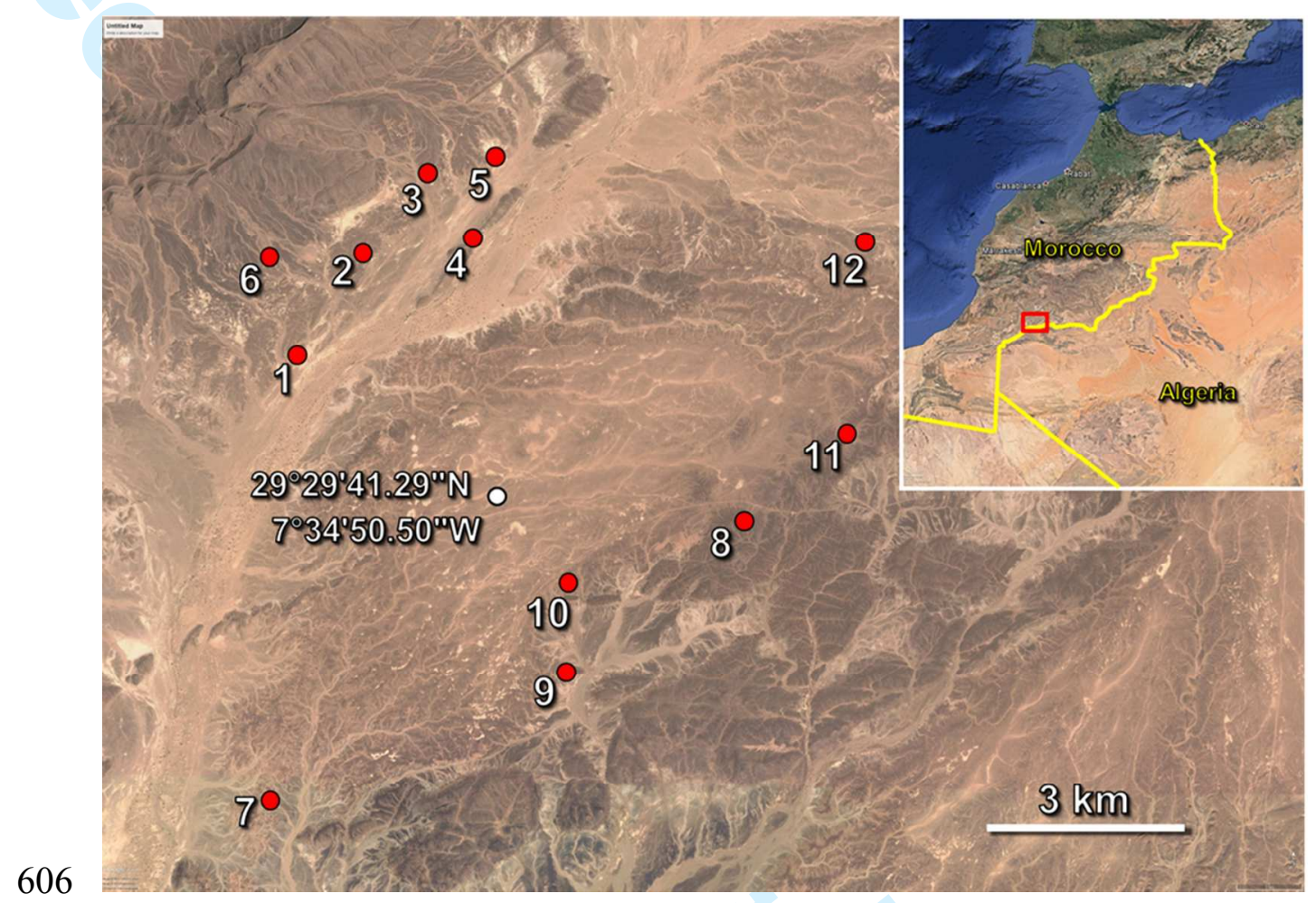

$607 \quad$ Figure 2

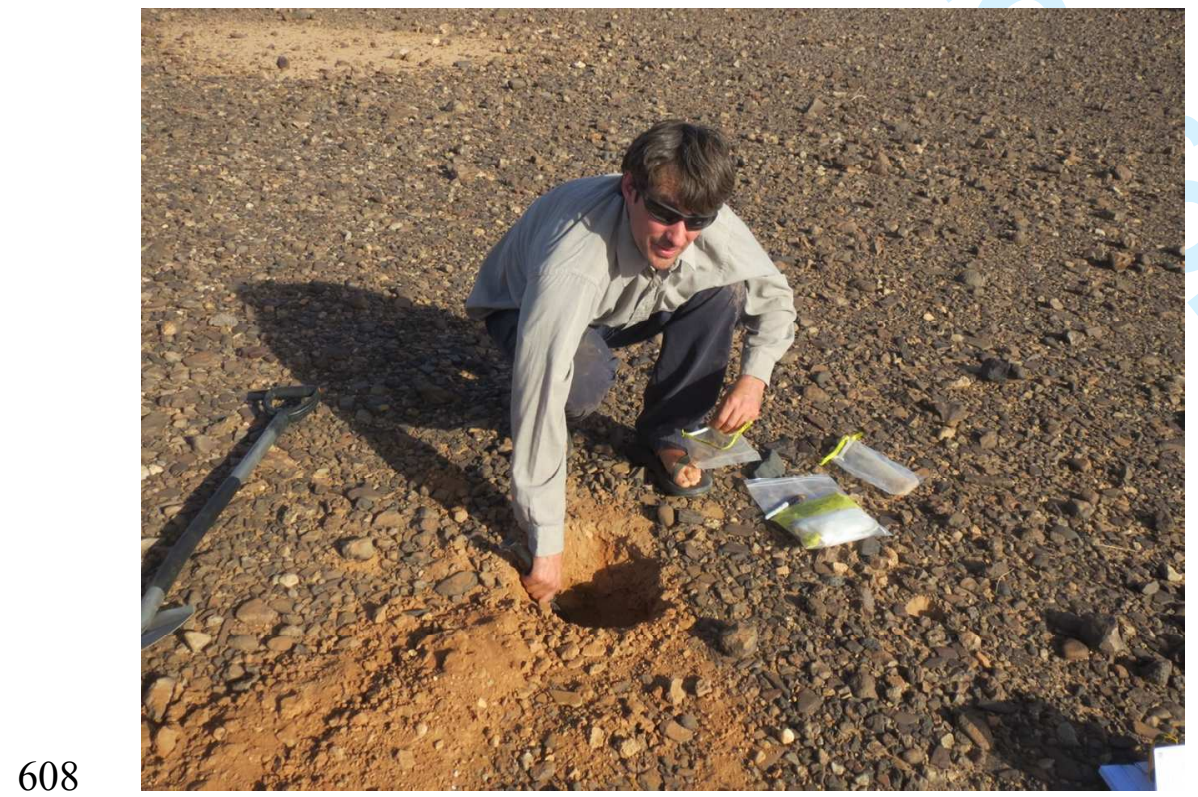




\section{$609 \quad$ Figure 3}

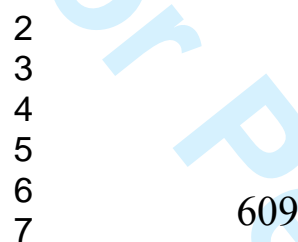

8

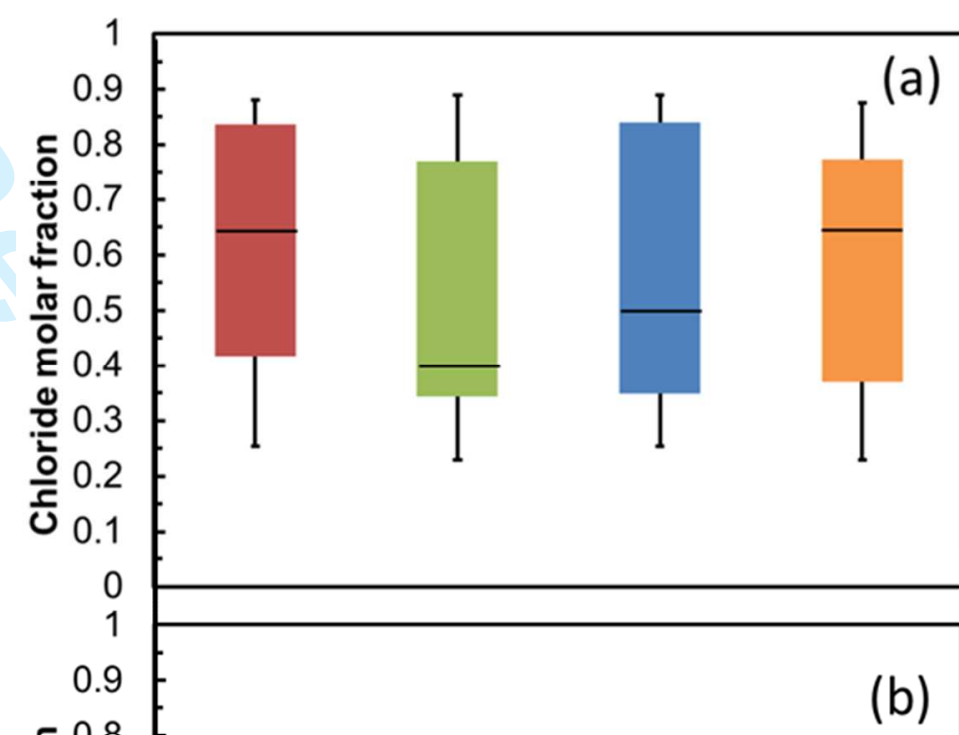


Submitted to Astrobiology (Special Issue)

\section{$612 \quad$ Figure 4}

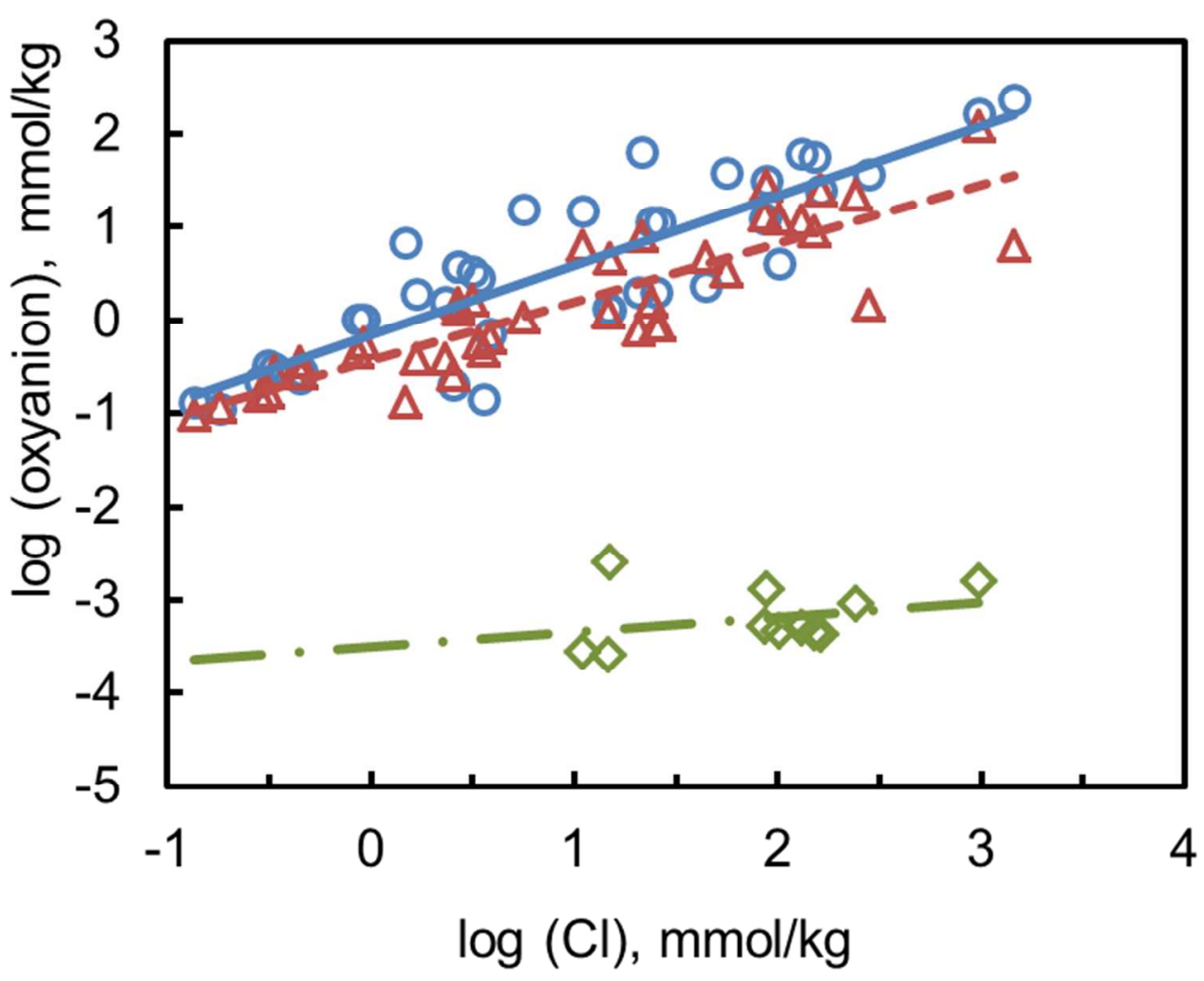

613

614 


\section{$615 \quad$ Figure 5}

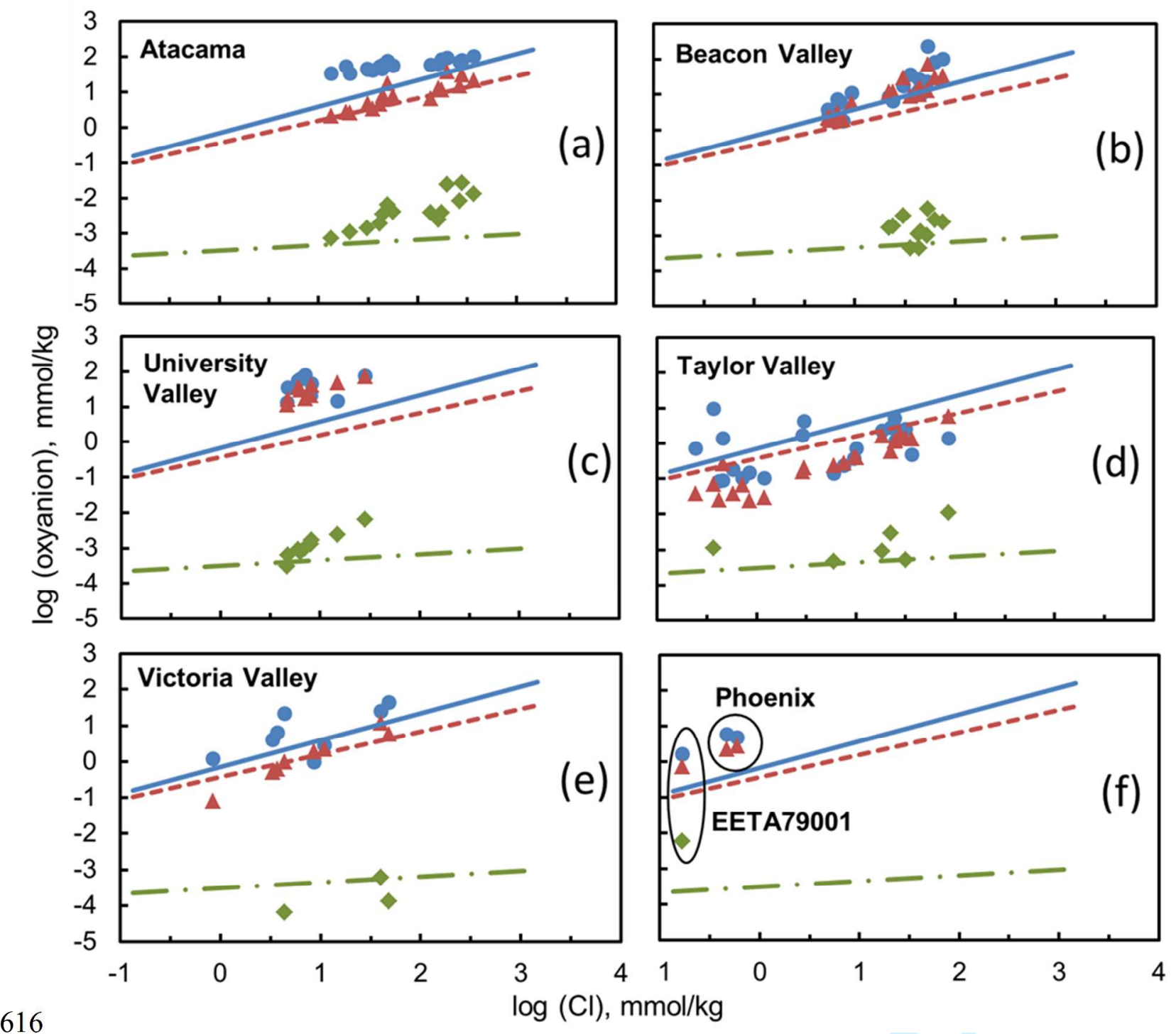

616

617 
Submitted to Astrobiology (Special Issue)

\section{$618 \quad$ Figure 6}

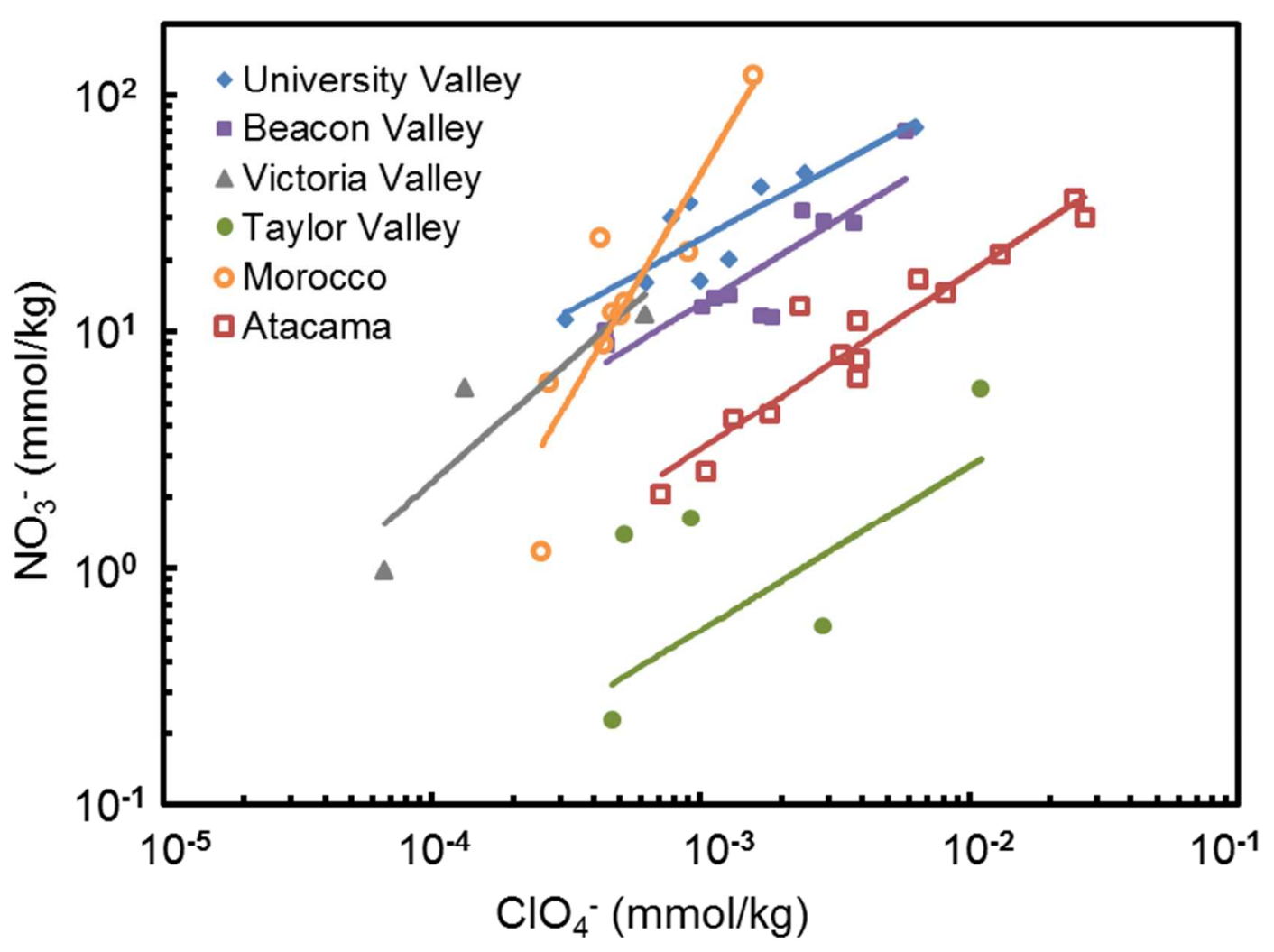

619

620 
$621 \quad$ Figure 7

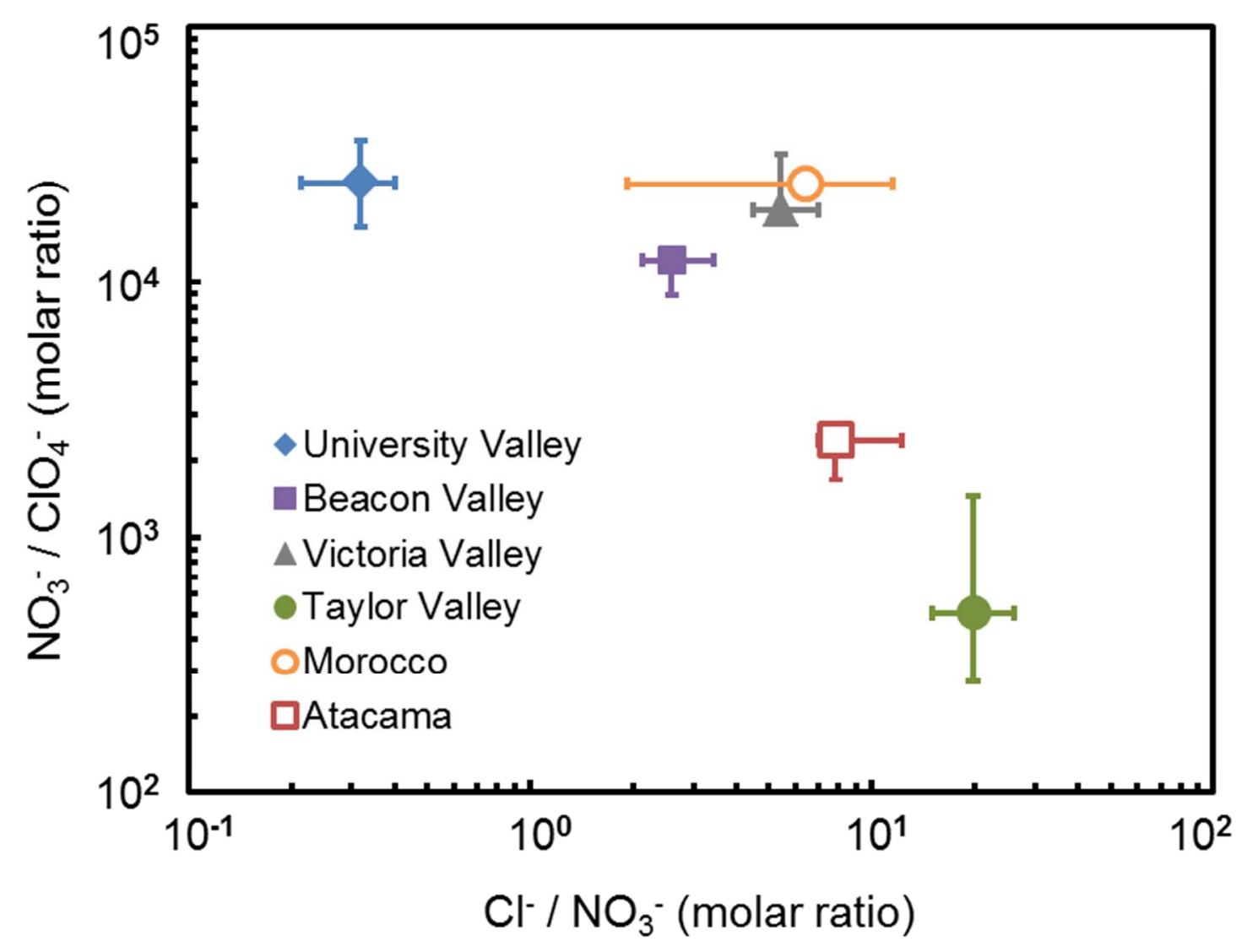

622 
Submitted to Astrobiology (Special Issue)

624

625

Figure 8

\begin{tabular}{l|l|l|l}
\hline & Noachian & Hesperian & Amazonian \\
\hline Morocco & & & \\
\hline Taylor & & & \\
\hline Victoria & & & \\
\hline Atacama & & & \\
\hline Beacon & & & \\
\hline University & & & \\
\hline EETA79001 & & \\
\hline Phx-WCL & & \\
\hline
\end{tabular}

626

627 